Тичковська Л. П., к.е.н., доцент Київський національний економічний університет імені Вадима Гетьмана м. Київ, Украӥна

Фрунза С. А., к.е.н., доцент Економіко-технологічний інститут імені Роберта Ельворті м. Кропивницький, Украӥна

Стенічева I. Б., асистент Придніпровська державна академія будівництва та архітектури м. Дніпро, Украӥна

DOI: https://doi.org/10.30525/978-9934-26-107-7-21

\title{
ОСОБЛИВОСТІ АНАЛІЗУ ФІНАНСОВО-ЕКОНОМІЧНОЇ СТІЙКОСТІ ПІДПРИЕМСТВА ЯК ЕЛЕМЕНТУ ЙОГО ФІНАНСОВОЇ СТАБІЛЬНОСТІ
}

У ринковій економіці фінансова стійкість підприємства $\epsilon$ головною умовою життєдіяльності та основою стабільності стану підприємства. Під фінансовою стійкістю підприємства розуміють властивість підприємства, яка відображає в процесі взаємодії зовнішніх та внутрішніх факторів впливу досягнення стану фінансової рівноваги і здатність не лише утримувати на відповідному рівні протягом деякого часу основні характеристики діяльності підприємства, але й функціонувати та розвиватися. Одним з визначених завдань сьогодення є забезпечення відносної фінансової рівноваги підприємства в процесі його розвитку. Така рівновага характеризується високим рівнем фінансової стійкості та платоспроможності підприємства і забезпечується формуванням раціональної структури майна та капіталу, ефективними пропорціями в обсягах формування фінансових ресурсів за рахунок різних джерел, достатнім рівнем самофінансування інвестиційних потреб. 
Розв'язанню проблеми забезпечення фінансової стійкості та прогнозування фінансової стабільності підприємства присвячені праці відомих вітчизняних дослідників, зокрема М. Лишенко, Є. Удовик, М. Коробов, Л. Лісовий, I. Чуницька. Проте, незважаючи на значні досягнення науковців, низка питань теоретико-методологічного та практичного характеру потребують детальнішого висвітлення і подальших наукових розвідок.

Оцінювання фінансової стійкості підприємства передбачає проведення об' єктивного аналізу величини та структури активів i пасивів підприємства і визначення на цій основі його фінансової стабільності і незалежності, а також аналізу відповідності фінансово-господарської діяльності підприємства цілям його статутної діяльності. Фінансово стійким є такий господарюючий суб'єкт, котрий за рахунок власних коштів покриває кошти, вкладені в активи (основні засоби, нематеріальні активи, оборотні кошти), не допускає невиправданої дебіторської та кредиторської заборгованості і розраховується за своїми зобов'язаннями в зазначений термін [2].

Саме оцінювання фінансової стійкості дозволяє зовнішнім користувачам визначити фінансові можливості підприємства в майбутньому. Основне завдання аналізу фінансової стійкості полягає у визначенні спроможності підприємства протистояти негативній дії різних факторів (зовнішніх, внутрішніх та непередбачуваних), що впливають на його фінансовий стан.

Важливим економічним аспектом $\epsilon$ визначення меж фінансової стійкості. Так, недостатня фінансова стійкість може призвести до неплатоспроможності підприємства і відсутності у нього коштів для розвитку виробництва і взагалі діяльності господарюючого суб'єкта. Надлишкова фінансова стійкість також негативно впливає на виробничогосподарську діяльність, оскільки виступає гальмом iі розвитку, збільшуючи затрати підприємства надлишковими запасами і резервами [4].

Інформаційний опис фінансової стійкості підприємства здійснюється на основі застосування системи бухгалтерського обліку на підприємстві. Головними інструментами оцінювання 
фінансової стійкості підприємства $є$ фінансові показники (коефіцієнти), які мають причинно-наслідковий зв'язок 3 результативним узагальнюючим показником.

Наявні методики аналізу фінансової стійкості підприємства передбачають проведення досліджень у декілька етапів. Залежно від завдань аналізу і тлумачення поняття «фінансова стійкість» порядок розрахунку показників у різних літературних джерел відрізняються. Але як правило, аналіз проводиться у такій послідовності:

1) загальна оцінка фінансової стійкості;

2) розрахунок за даними балансу системи відносних показників фінансової стійкості;

3) розрахунок за даними балансу системи абсолютних показників, які характеризують забезпеченість запасів джерелами формування i дають можливість визначити відповідний тип фінансової стійкості підприємства;

4) розрахунок за даними звіту про фінансові результати та факторний аналіз порогу рентабельності і запасу фінансової стійкості.

Загальне оцінювання фінансової стійкості передбачає визначення:

1) стійкості джерел формування капіталу;

2) ресурсної стійкості;

3) стійкості управління.

Аналізуючи фінансову стійкість необхідно розрахувати комплекс відносних показників. Відповідно до показника забезпечення запасів і витрат власними та позиченими коштами можна назвати такі типи фінансової стійкості підприємства:

1) абсолютна фінансова стійкість (трапляється на практиці дуже рідко) - коли власні оборотні кошти (ВОК) забезпечують запаси (3), а тому підприємство не залежить від банківських кредитів, має абсолютну ліквідність і забезпечує поточну та перспективну платоспроможність.

2) нормально стійкий фінансовий стан - коли запаси забезпечуються сумою власних оборотних коштів та довгостроковими 
позиковими джерелами (сума власних оборотних коштів i довгострокових зобов'язань складає функціонуючий капітал ФК). При цьому, підприємство має нормальну ліквідність і платоспроможність, а також достатньо рентабельною $є$ його операційна діяльність [3].

3) нестійкий фінансовий стан - коли запаси забезпечуються за рахунок власних оборотних коштів, довгострокових позикових джерел та короткострокових кредитів і позик, тобто за рахунок усіх основних джерел формування запасів і витрат; $є$ недостатньою ліквідність, виникає періодична неплатоспроможність, сповільнюється оборотність додаткових джерел фінансування. Однак, при цьому є можливість відновлення платоспроможності. Сума функціонуючого капіталу і короткострокових кредитів та позик складає загальну величину основних джерел формування запасів - ЗВ.

4) кризовий фінансовий стан - коли запаси й витрати не забезпечуються джерелами їх формування i підприємство перебуває на межі банкрутства. Підприємство має хронічну прострочену заборгованість перед кредиторами, а відновлення платоспроможності без санації є майже неможливим [1]. Моделі визначення типу фінансової стійкості представлені (табл. 1).

Таблиця 1

Модель визначення типу фінансової стійкості

\begin{tabular}{|c|c|c|c|c|c|}
\hline \multirow[b]{2}{*}{$\begin{array}{c}\text { № } \\
\text { ПI/II }\end{array}$} & \multirow[b]{2}{*}{$\begin{array}{c}\text { Показники, } \\
\text { надлишок (+) } \\
\text { нестача (-) }\end{array}$} & \multicolumn{4}{|c|}{ Тип фінансової стійкості } \\
\hline & & $\begin{array}{c}\text { Абсолютна } \\
\text { фінансова } \\
\text { стійкість }\end{array}$ & $\begin{array}{c}\text { Нормальна } \\
\text { фінансова } \\
\text { стійкість }\end{array}$ & $\begin{array}{c}\text { Нестійкій } \\
\text { фінансовий } \\
\text { стан }\end{array}$ & $\begin{array}{c}\text { Кризовий } \\
\text { фінансовий } \\
\text { стан }\end{array}$ \\
\hline 1. & $\pm \mathrm{BOK}=\mathrm{BOK}-3$ & $\pm \mathrm{BOK} \geq 0$ & $\pm \mathrm{BOK}<0$ & $\pm \mathrm{BOK}<0$ & $\pm \mathrm{BOK}<0$ \\
\hline 2. & $\pm \Phi К=\Phi К-3$ & $\pm \Phi К \geq 0$ & $\pm \Phi К \geq 0$ & $\pm \Phi К<0$ & $\pm \Phi К<0$ \\
\hline 3. & $\pm 3 B=3 B-3$ & $\pm 3 \mathrm{~B} \geq 0$ & $\pm 3 B \geq 0$ & $\pm 3 \mathrm{~B} \geq 0$ & $\pm 3 \mathrm{~B}<0$ \\
\hline
\end{tabular}

Фінансово-економічні коефіцієнти та абсолютні показники типу фінансової стійкості визначаються за інформацією бухгалтерського балансу і характеризують фінансову стабільність 
підприємства 3 погляду співвідношення власних і залучених фінансових ресурсів [4].

Отже, фінансова стійкість $є$ однією 3 найважливіших характеристик фінансово-економічної діяльності підприємства в умовах ринкової економіки. Якщо підприємство фінансово стійке, то воно має перевагу перед іншими підприємствами того ж профілю в залученні інвестицій, в одержанні кредитів, у виборі постачальників і в підборі кваліфікованих кадрів. Воно не вступає в конфлікт із державою i суспільством, тому що функціонування підприємства є фінансово стабільним, виплачує вчасно податки в бюджет, внески в соціальні фонди, заробітну плату, а банкам гарантує повернення кредитів і сплату відсотків по них.

\section{Література:}

1. Косарєва І.П., Удовик С.М. Удосконалення системи управління фінансовою стійкістю підприємств. Глобальні та наџіональні проблеми економіки (електронне наукове видання). 2018. № 23. C. 246-251. URL: http://global-national.in.ua/archive/23-2018/48.pdf

2. Коробов М.Я. Фінансово-економічний аналіз діяльності підприємств: навч. посіб. Київ : Знання, 2000. 378 с.

3. Савицкая Г.В. Анализ хозяйственной деятельности предприятия. Минск : Новое знание, 2002. 704 с.

4. Лісовий А.В., Чуницька І.І. Аналіз фінансових ресурсів як базис формування фінансового потенціалу. Бізнес-Навігатор. 2010. Вип. 21. C. 96-101. 